\title{
Neuroprotective Effects of Methylene Blue on Scopolamine-Induced Amnesia via Anti-Cholinesterase and Anti-oxidative Activities in Adult Rat
}

\author{
Ahmed M. Shehata \\ Physiology Department- National Organization for \\ Drug Control and Research
}

\begin{abstract}
Methylene blue (MB) is currently used to treat methemoglobinemia, a blood disorder. But because high concentrations of methylene blue were known to damage the brain, no one thought to experiment with low concentrations. The study aimed to evaluate the possible protective effect of methylene blue against scopolamine induced-amnesia in adult rats. Methylene blue (2 and $5 \mathrm{mg} / \mathrm{kg}$, i.p.) was administered separately or concurrently with scopolamine administration $(1 \mathrm{mg} / \mathrm{kg}$, i.p). Results showed that scopolamine induced amnesia in passive avoidance task, increased the catalytic activity of total cholinesterase and decreased content of acetylcholine depressed the level of reduced glutathione (GSH) and total antioxidant activity in the hippocampus and brain cortex. Methylene blue dose-dependently inhibited the enzymatic activity of total cholinesterase and increased the acetylcholine content, increased GSH content and total antioxidant activity in the hippocampus and brain cortex. Concurrent treatment of $M B$ dose-dependently minimized both amnesic and anti-cholinergic effect of scopolamine. The study indicated that MB could protect against the scopolamine effects at low doses through its enhancing effect on cholinergic pathways and anti-oxidative activities. Methylene blue with its neuroprotective effects and could thus act as disease modifiers in patients, slowing the progression of behavioral deterioration since acetylcholinesterases themselves could contribute to the degenerative process.
\end{abstract}

Keywords: Alzheimer- scopolamine- methylene blue- cholinergic system- oxidative stress.

\section{INTRODUCTION}

Alzheimer's disease is a progressive, ultimately fatal, disorder in which certain types of nerve cells in particular areas of the brain degenerate and die for unknown reasons $^{(\mathbf{1})}$. However, it has been suggested that oxidative damage is one of the most integral neurotoxic mechanisms in both amyloid $\beta \quad(\mathrm{A} \beta)$ accumulation and tau pathologies ${ }^{(2,3,4)}$. Specifically, increased oxidative damage to brain lipids, carbohydrates, proteins and DNA has been reported to be involved in AD pathogenesis ${ }^{(5,6)}$. The vulnerable brain regions include the hippocampus and cortical area comprising cell populations involved in catecholaminergic, serotonergic and cholinergic neurotransmission ${ }^{(7-9)}$. The hippocampus is the processing 
center for different information, experience and memory consolidation $^{(\mathbf{1 0 )}}$. Various environmental stimuli, such as exploration, stress, or learning, increase acetylcholine $(\mathrm{ACh})$ release to activate hippocampal functions ${ }^{(\mathbf{1 1})}$. In addition, the drugs acting on the cholinergic system can improve or worsen cognitive abilities ${ }^{(\mathbf{1 2})}$. Consistently, the postmortem brain from Alzheimer's disease patients shows several indices of reduced cholinergic function, including deficits in the enzyme responsible for the synthesis of acetylcholine (ACh), choline acetyl-transferase, reduced ACh release, and loss of cholinergic neurons in the specific brain areas ${ }^{(4)}$.

Scopolamine is muscarinic receptor antagonist with amnestic property that has been used for decades in experimental animals to induce impairment in their performance of a variety of tasks requiring intact working and reference memory ${ }^{(13,14)}$. For many years, the amnestic action produced in animals by the administration of centrally acting muscarinic cholinergic antagonists, particularly scopolamine, has been a widely used model for the characterization of potential cognition-enhancing drugs $^{(15)}$. However, the experimental models of memory impairment have been suggested to be of limited value because they fail to replicate the pathological aspects and the progressive degenerative nature of Alzheimer's disease ${ }^{(\mathbf{1 6})}$. Despite this limitation, scopolamine-induced memory impairment, particularly when coupled with a version of the inhibitory avoidance task provides a relatively rapid phenotypic screening tool for drug discovery in the field of cognition enhancement.

Methylene blue (MB) is a diaminophenothiazine that has been in clinical use for approximately 100 years to treat a variety of ailments. MB treats congenital and poisoninduced methemoglobinemia; prevents the side effects of chemotherapy $^{(\mathbf{1 7}, 18)}$, and treats septic shock $^{(19)}$. The dose of MB usually used in clinical settings is between 1 and $2 \mathrm{mg} / \mathrm{kg} / \mathrm{day}^{(\mathbf{2 0})}$; and signs of toxicity start at higher levels (7.5 $\mathrm{mg} / \mathrm{kg} /$ day $)^{(\mathbf{2 1})}$.

The therapeutic potential of MB also has been demonstrated in models for specific ailments. MB protects against endotoxin-induced lung injury, bacterial lipopolysaccharideinduced fever ${ }^{(22,23)}$, and cyclosporine injury to the kidney ${ }^{(24)}$. Methylene blue administration in vivo appears to benefit the central nervous system and cognitive function ${ }^{(25)}$, protects from methylmalonate induced seizures ${ }^{\mathbf{( 2 6 )}}$, and protects from the cognitive decline inflicted by inhibitors of complex IV ${ }^{(27)}$.

The present study aims to study the possible protective effect of $\mathrm{MB}$ in scopolamine- induced amnesia in rats and explore the neurochemical basis of this effect.

\section{MATERIALS \& METHODS}

Experimental animals: male adult Sprague Dawley rats (150-200 g) were kindly provided from our breeding center at NODCAR and kept for a week for acclimatization under normal conditions and constant temperature $\left(25 \pm 1 \mathrm{C}^{\circ}\right)$ with ad libitum 
water and food until starting the experiment.

Chemicals:

All chemicals, unless specified otherwise, were purchased form Sigma-Aldrich Chemical Co. (St. Louis, MO). Scopolamine and methylene blue were dissolved in saline.

\section{Animal grouping:}

A total number of forty eight Sprague Dawley rats with an average weight of $175 \pm 5 \mathrm{~g}$, was divided into six groups:

- Control group: the rats intraperitoneally administered $1 \mathrm{ml}$ saline solution.

- Methylene group-2: the rats were intraperitoneally administered single dose of methylene blue ( $2 \mathrm{mg} / \mathrm{g})$.

- Methylene group-5: the rats were intraperitoneally administered single dose of methylene blue $(5 \mathrm{mg} / \mathrm{g})$.

- Methylene group-2 plus scopolamine: the rats were intraperitoneally administered single dose of methylene blue (2 $\mathrm{mg} / \mathrm{g}$ ), followed by scopolamine 30 minutes later ( $1 \mathrm{mg} / \mathrm{kg}$, i.p).

- Methylene group-5 plus scopolamine: the rats were intraperitoneally administered single dose of methylene blue $(5 \mathrm{mg} / \mathrm{g})$, followed by scopolamine 30 minutes later $(1 \mathrm{mg} / \mathrm{kg}$, i.p).

- Scopolamine group: the rats were intraperitoneally administered single dose of scopolamine $(1 \mathrm{mg} / \mathrm{kg})$.

Passive avoidance test

Passive avoidance test, which is a fear-motivated test classically used to assess the effect of different treatments on memory ${ }^{(28)}$. The apparatus was equipped with identical illuminated and non-illuminated boxes with a guillotine door $(5 \times 5 \mathrm{~cm})$. The illuminated compartment $(20 \times 20 \times 20 \mathrm{~cm})$ contained a $50-\mathrm{W}$ bulb, and the floor of nonilluminated compartment $(20 \times 20 \times 20 \mathrm{~cm})$ was composed of $2 \mathrm{~mm}$ stainless steel rods spaced $1 \mathrm{~cm}$ apart. A rat was gently placed in the illuminated compartment for an acquisition trial, and the door between the two compartments was opened after $10 \mathrm{sec}$. When the rat entered the dark compartment, the door was closed and an electrical foot shock (0.5 mA, $3 \mathrm{sec}$ duration) was delivered through the stainless steel rods. Twenty-four hours after this acquisition trial, the mouse was again placed in the illuminated compartment for a retention trial. The time taken for a mouse to enter the dark compartment after door opening was defined as latency time for both acquisition and retention trials. Latency for entering the dark compartment was recorded up to 300 sec. If a rat did not enter the dark compartment within $300 \mathrm{sec}$, the rat was removed and assigned a latency score of $300 \mathrm{sec}$. Methylene blue and scopolamine were dissolved in $0.9 \%$ saline. Methylene blue doses were given $1 \mathrm{~h}$ after the acquisition trial. Memory impairment was induced in rat with scopolamine $(1 \mathrm{mg} / \mathrm{kg}$, i.p.) $30 \mathrm{~min}$ after methylene blue treatment. The control group received saline solution only. Following the behavioral study, the rats were decapitated and brain was dissected into cortex and hippocampus.

- Acetylcholine was determined according to HPLC $^{(29)}$. Total 
cholinesterase activity was determined according to method of Ellman ${ }^{(30)}$. Reduced glutathione levels were determined according to the Jayatilleke and Shaw ${ }^{(31)}$. Total antioxidant activity was determined using the colorimetric method of Blois $^{(32)}$

\section{Statistical Analysis.}

Data presented as means \pm SE. One-way ANOVA followed by LSD test were used to evaluate significant differences from the control and SCPtreated groups. $P<0.05$ was considered to be statistically significant. Statistical processor system support (SPSS) for Windows software, release 10.0 (SPSS, Inc, Chicago, IL) was used.

\section{RESULTS}

Data in tables 1, 2 and 3 show that scopolamine treatment significantly increased ChE activity and decreased ACh content, and depressed total antioxidant activity and GSH level in brain cortex and hippocampus. Methylene blue treatment dose dependently decreased ChE activity and increased ACh content, total antioxidant activity and GSH content in brain cortex and hippocampus compared with control group (Table 1, 2 and 3). Whereas, MB pretreatment dose dependently normalized ChE activity and levels of $\mathrm{ACh}, \mathrm{GSH}$ and total antioxidant activity in brain cortex and hippocampus (Tables 1, 2 and 3). In passive avoidance task, scopolamine administration decreased the retention time. Methylene blue treated rats exhibited higher retention time compared with control and scopolamine treated rats. Pretreatment of $\mathrm{MB}$ dose dependently attenuated the scopolamine effects (Fig.1).

Table (1): Effect of Methylene Blue (MB) Pre-treatment (2 and $5 \mathrm{mg} / \mathrm{kg}$, i.p) (MB-2 and MB-5, respectively) on Acetylcholine (ACh) Content and Total Cholinesterase (ChE) Activity in Brain Cortex of Scopolamine (SCP, $1 \mathrm{mg} / \mathrm{kg}$, i.p.) -Treated Rats.

\begin{tabular}{l|lc}
\hline Groups & $\begin{array}{l}\text { ChE } \\
(U / g \text { tissue } w t)\end{array}$ & $\begin{array}{l}\text { ACh } \\
(\mu \mathrm{g} / \mathrm{g} \text { tissue } w t)\end{array}$ \\
\hline Control & $4040.50 \pm 74.70$ & $1.63 \pm 0.08$ \\
MB-2 & $3240.83 \pm 60.31^{*,+}$ & $1.82 \pm 0.06^{*,+}$ \\
MB-5 & $2941.50 \pm 22.69^{*,+}$ & $2.27 \pm 0.06^{*,+}$ \\
MB-2+SCP & $4428.17 \pm 338.60^{+}$ & $1.41 \pm 0.05^{*,+}$ \\
MB-5 +SCP & $4588.33 \pm 175.44^{*,+}$ & $1.60 \pm 0.03^{+}$ \\
SCP & $5888.33 \pm 242.15^{*}$ & $0.74 \pm 0.06^{*}$ \\
\hline
\end{tabular}

Data presented as means \pm S.E. $(n=8), P<0.05$ was considered to be statistically significant

* Significant different from control group

${ }^{+}$Significant different from scopolamine treated rats 
Table (2): Effect of Methylene Blue (MB) Pre-treatment (2 and $5 \mathrm{mg} / \mathrm{kg}$, i.p) (MB-2 and MB-5, respectively) on Acetylcholine (ACh) Content and Total cholinesterase (ChE) Activity in Brain Hippocampus of Scopolamine (SCP, $1 \mathrm{mg} / \mathrm{kg}$, i.p.) - Treated Rats.

\begin{tabular}{l|ll}
\hline Groups & $\begin{array}{l}\text { ChE } \\
(U / g \text { tissue wt })\end{array}$ & $\begin{array}{l}\text { ACh } \\
(\mu \mathrm{g} / \mathrm{g} \text { tissue wt })\end{array}$ \\
\hline Control & $3870.00 \pm 75.63$ & $1.63 \pm 0.06$ \\
MB-2 & $3150.00 \pm 81.65^{*,+}$ & $1.95 \pm 0.07^{*,+}$ \\
MB-5 & $2743.67 \pm 90.20^{*,+}$ & $2.28 \pm 0.18^{*,+}$ \\
MB-2+SCP & $4270.33 \pm 94.53^{*,+}$ & $1.54 \pm 0.04^{+}$ \\
MB-5 +SCP & $3727.33 \pm 101.95^{+}$ & $1.58 \pm 0.06^{+}$ \\
SCP & $6031.00 \pm 138.94^{*}$ & $0.78 \pm 0.04^{*}$ \\
\hline
\end{tabular}

Data presented as means \pm S.E. $(n=8), P<0.05$ was considered to be statistically significant

* Significant different from control group

${ }^{+}$Significant different from scopolamine treated rats

Table (3): Effect of Methylene Blue (MB) Pre-treatment (2 and $5 \mathrm{mg} / \mathrm{kg}$, i.p) (MB-2 and MB-5, respectively) on Total antioxidant activity and Reduced glutathione (GSH) Content in Brain Cortex and Hippocampus of Scopolamine (SCP, $1 \mathrm{mg} / \mathrm{kg}$, i.p.) Treated Rats.

\begin{tabular}{l|lll}
\hline Brain Areas & Groups & $\begin{array}{l}\text { Total Antioxidant Activity } \\
\text { (\% inhibition of DPPH) }\end{array}$ & $\begin{array}{l}\text { Reduced glutathione } \\
\text { Ug/g }\end{array}$ \\
\hline Cortex & Control & $59.17 \pm 1.54$ & $1.51 \pm 0.05$ \\
& MB-2 & $77.50 \pm 4.23^{*,+}$ & $1.69 \pm 0.05^{*,+}$ \\
& MB-5 & $83.67 \pm 3.93^{*,+}$ & $1.78 \pm 0.04^{*,+}$ \\
& MB-2+SCP & $57.50 \pm 2.81^{+}$ & $1.44 \pm 0.05^{+}$ \\
& MB-5+SCP & $55.00 \pm 3.16^{+}$ & $1.55 \pm 0.04^{+}$ \\
& SCP & $40.00 \pm 2.24^{*}$ & $1.17 \pm 0.04^{*}$ \\
& Control & $60.83 \pm 5.54^{*,+}$ & $1.61 \pm 0.05^{*,+}$ \\
& MB-2 & $73.00 \pm 3.65^{,+}$ & $1.77 \pm 0.04^{*+}$ \\
& MB-5 & $78.00 \pm 2.82^{*,+}$ & $1.89 \pm 0.03^{*+}$ \\
& MB-2+SCO & $55.17 \pm 2.89^{+}$ & $1.53 \pm 0.04^{+}$ \\
& MB-5+SCO & $62.67 \pm 2.19^{+}$ & $1.69 \pm 0.06^{+}$ \\
& SCO & $40.00 \pm 3.87^{*}$ & $1.24 \pm 0.03^{*}$ \\
\hline
\end{tabular}

Data presented as means \pm S.E. $(n=8), P<0.05$ was considered to be statistically significant

* Significant different from control group

${ }^{+}$Significant different from scopolamine treated rats. 


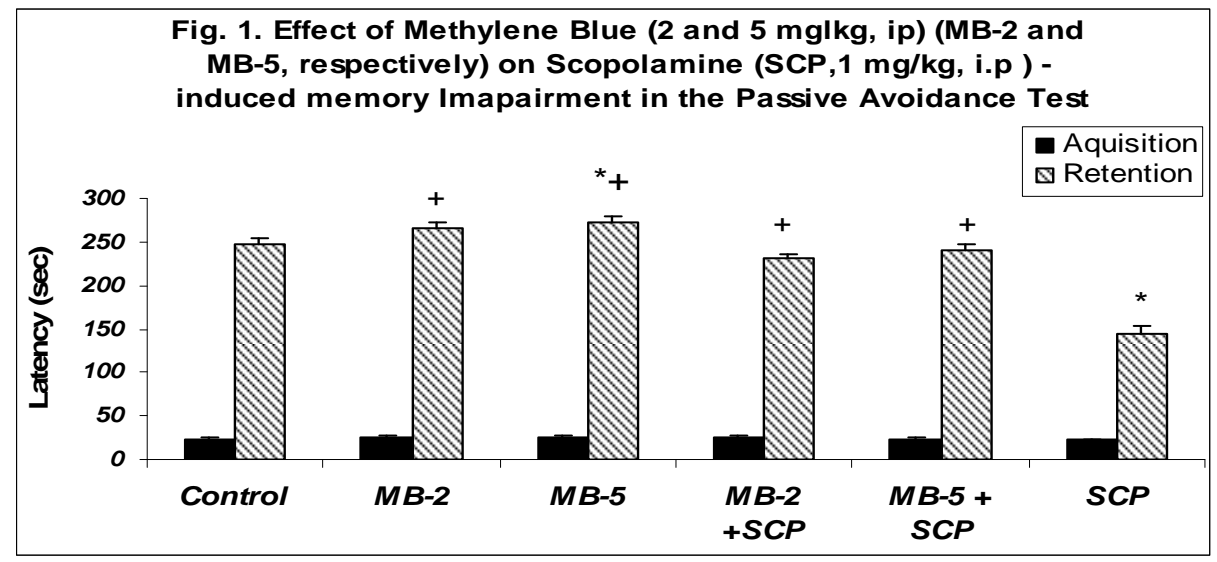

Data presented as means \pm S.E. $(\mathrm{n}=8), P<0.05$ was considered to be statistically significant

* Significant different from control group

${ }^{+}$Significant different from scopolamine treated rats

\section{DISCUSSION}

The present study showed that scopolamine treated rats exhibited decreased level of $\mathrm{ACh}$ and increased catalytic activity of total cholinesterase in both brain cortex and hippocampus, due to the increased turn over of $\mathrm{ACh}$ as a result of $\mathrm{ChE}$ activation under scopolamine treatment. It might be speculated that scopolamine reversibly binds to some allosteric site in $\mathrm{ChE}$ molecule causing a change in its secondary structure leading to increased catalytic activity and decreased ACh content. In accordance, several studies indicated that scopolamine administration leads to the activation of AChE enzyme ${ }^{(33-35)}$. In addition, scopolamine induces oxidative stress possibly by impairing mitochondrial function, and/or AChE activation and subsequent ACh depletion. Consistently to this interpretation, recent previous studies demonstrated the involvement of AChE activity in a cellular model of oxidative stress ${ }^{(36)}$. In accordance, several studies liked the cholinergic dysfunction with the occurrence of oxidative stress ${ }^{(37,38)}$. Besides, both cholinergic dysfunction and oxidative stress play reciprocal roles in Alzheimer disease ${ }^{(39)}$.

In the present study, methylene blue demonstrated an antioxidant effect and cholinergic neurotransmission potentiation through increasing GSH content and total antioxidant activity and inhibition of ChE activity and elevating $\mathrm{ACh}$ content in both brain cortex and hippocampus. In accordance, several studies indicated the antioxidant and the inhibitory effect of MB on ChE activity ${ }^{(40,41)}$.

In addition, $\mathrm{MB}$ pretreatment antagonized scopolamine- induced cholinergic dysfunction and oxidative stress, in a dose dependent manner. 
This effect might be due to the antioxidant and augmenting effect $\mathrm{MB}$ on cholinergic transmission. Because its redox potential is close to zero, $\mathrm{MB}$ is very efficient in cycling between oxidized and reduced forms by suitable redox centers and reducing agents such as those in the mitochondria ${ }^{(42)}$. $\mathrm{MB}$ is efficiently reduced by NAD (P) $\mathrm{H}$ dependent dehydrogenases to form the colorless $\mathrm{MBH} 2{ }^{(\mathbf{4 2})}$. Electron delocalization in $\mathrm{MB}$ results in a partial positive charge located on both nitrogen and sulfur atoms, which may increase the permeability of MB through membranes. The lipid solubility of $\mathrm{MBH} 2$ is higher than for MB; thus, both forms enter the mitochondria ${ }^{(43)}$. In accordance, several studies show that $\mathrm{MB}$ increases brain oxygen consumption, improves mitochondrial respiration and prevents free radical damage by serving as a redox compound at low doses and improves brain function (25,44- 47). In addition, methylene Blue (MB),is efficiently trapped in the brain and its concentration is over 10 times higher in the brain than in the circulation one hour after systemic administration ${ }^{(48)}$, indicating a rapid and extensive accumulation in the nervous system. Moreover, MB has been used as a neuroprotective agent in druginduced encephalopathy, dementia and manic-depressive psychosis ${ }^{(49)}$.

In the present study scopolamine treated group showed defective performance in passive avoidance task, indicating the occurrence of the amnesia. This effect might be, at least, due to cholinergic dysfunction and/or oxidative stress. In accordance, previous studies indicated the amnestic effect of scopolamine ${ }^{\mathbf{( 5 0 - 5 2 )}}$. The observation that methylene blue treatment significantly activates memory and antagonized the amnestic effect of scopolamine is probably due to its activating effect of mitochondrial function and cholinergic up regulating effect in brain cortex and hippocampus. Consistent to this interpretation, several studies indicating the beneficial effect of MB with low doses on memory and brain function $^{(42,46)}$, by enhancing the cholinergic neurotransmission ${ }^{(\mathbf{1 2}, 53)}$.

The study provides a demonstration of the neuroprotective effects of methylene blue in scopolamine-induced amnesia. Coadministration of $\mathrm{MB}$, within the safe range $(2-5 \mathrm{mg} / \mathrm{kg}$, i.p.), provided effective protection against oxidative stress and cholinergic dysfunction, the main culprits in Alzheimer's disease. Although methylene blue merely presents a protective potential and may not cure Alzheimer's disease, yet any drug that reverses symptoms, improves quality of life, delays neurodegeneration, and saves huge costs, represents an important step in progress towards curing Alzheimer's disease.

\section{REFERENCES}

1- Kalman, S., Pakaski, M., Szucs, S., Kalman, J. Jr., Fazekas, O., Santha, P., Szabo, G., Janka, Z. and Kalman, J. (2010): 9hydroxy-risperidone (9OHRIS) prevents stress-induced $\beta$-actin overexpression in rat hippocampus. 
Neuropsychopharmacol Hung.; 12(3): 425-431.

2- Ballatore, C., Lee, V. M., and Trojanowski, J. Q. (2007): Taumediated Neurodegeneration in Alzheimer's disease and related disorders. Nat. Rev. Neurosci. 8, 663-672.

3- Halliwell, B., and Gutteridge, J. M. C. (2007). Free Radicals in Biology and Medicine. New York: Oxford University Press.

4- Kadir, A., Marutle, A., Gonzalez, D., Scholl, M., Almkvist, O., Mousavi, M., Mustafiz, T., Darreh-Shori, T., Nennesmo, I. and Nordberg, $A$. (2011): Positron emission tomography imaging and clinical progression in relation to molecular pathology in the first Pittsburgh Compound B positron emission tomography patient with Alzheimer's disease. Brain: 134; 301-317

5- Butterfield, D. A. and Lauderback, C. M. (2002). Lipid peroxidation and protein oxidation in Alzheimer's disease brain: potential causes and consequences involving amyloid beta-peptide-associated free radical oxidative stress. Free Radic. Biol. Med. 32, 1050-1060.

6- Mariani, E., Polidori, M. C., Cherubini, A. and Mecocci, $P$. (2005). Oxidative stress in brain aging, neurodegenerative and vascular diseases: an overview. $J$. Chromatogr. B Analyt. Technol. Biomed. Life Sci. 827, 65-75.

7- Roland, J.J., Mark, K., Vetreno, R.P. and Savage, L. M. (2008): Increasing hippocampal acetylcholine levels enhances behavioral performance in an animal model of diencephalic amnesia. Brain Res.; 1234: 116-127.

8- Martorana A., Mori F., Esposito Z, Kusayanagi H., Monteleone F., Codeca C., Sancesario, G., Bernardi, G. and Koch, G. (2009): Dopamine modulates cholinergic cortical excitability in Alzheimer's disease patients. Neuropsychopharmacology 34, 2323-2328

9- Angelucci, F., Bernardini, S., Gravina, P., Bellincampi, L., Trequattrini, A., Di Iulio, F., Vanni, D., Federici, G., Caltagirone, C., Bossù, P. and Spalletta, G. (2009): Delusion symptoms and response to antipsychotic treatment are associated with the 5-HT2A receptor polymorphism $(102 \mathrm{~T} / \mathrm{C})$ in Alzheimer's disease: a 3-year follow-up longitudinal study. $J$ Alzheimer's Dis.; 17(1):203-211.

10- Gupta, A.S., van der Meer, M.A., Touretzky, D.S. and Redish, A.D. (2010): Hippocampal replay is not a simple function of experience. Neuron; 65(5):695-705

11- Mitsushima, D. (2010): Sex steroids and acetylcholine release in the hippocampus. Vitam Horm.82:263-277

12- Desmarais, J.E. and Gauthier, S. (2010): Alzheimer disease: clinical use of cholinergic drugs in Alzheimer disease. Nat. Rev. Neurol. 6(8):418-420.

13- Kulkarni, K.S., Kasture, S.B. and Mengi, S.A. (2010): Efficacy study of Prunus 
amygdalus (almond) nuts in scopolamine-induced amnesia in rats. Indian. J. Pharmacol.; 42 (3):168-173

14- Souza, A.C., Brüning, C.A., Leite, M.R., Zeni, G. and Nogueira, C.W. (2010): Diphenyl diselenide improves scopolamine-induced memory impairment in mice. Behav. Pharmacol.; 21 (5-6):556-562

15- Girisha, H.R., Narendra Sharath Chandra, J.N., Boppana, S., Malviya, M., Sadashiva, C.T. and Rangappa, K.S. (2009): Active site directed docking studies: synthesis and pharmacological evaluation of cis-2, 6-dimethyl piperidine sulfonamides as inhibitors of acetylcholinesterase. Eur. J. Med. Chem.; 44 (10):4057-4062

16- Van Dam, D. and De Deyn, P.P. (2006): Drug discovery in dementia: The role of rodent models. Nature Rev. Drug Discovery; 5: 956-970

17- Pelgrims, J., De Vos, F., Van den Brande, J., Schrijvers, D., Prove, A., and Vermorken, J. B. (2000): Methylene blue in the treatment and prevention of ifosfamide-induced

encephalopathy: report of 12 cases and a review of the literature. Br. J. Cancer 82, 291294

18- Patel, P. N. (2006): Methylene blue for management of ifosfamide- induced encephalopathy. Ann. Pharmacother. 40, 299-303

19- Kwok, E. S. and Howes, D. (2006): Use of methylene blue in sepsis: a systematic review. J. Intensive Care Med. 21, 359-363

20- Clifton, J., 2nd, and Leikin, J. B. (2003): Methylene blue. Am. J. Ther. 10, 289-291

21- Sweet, G., and Standiford, S.B. (2007): Methylene-blueassociated encephalopathy. J. Am. Coll. Surg. 204, 454-458

22- Demirbilek, S., Sizanli, E., Karadag, N., Karaman, A., Bayraktar, N., Turkmen, E. and Ersoy, M. O. (2006): The effects of methylene blue on lung injury in septic rats. Eur. Surg. Res. 38, 35-41

23- Riedel, W., Lang, U., Oetjen, U., Schlapp, U. and Shibata, M. (2003): Inhibition of oxygen radical formation by methylene blue, aspirin, or alpha-lipoic acid, prevents bacteriallipopolysaccharide- induced fever. Mol. Cell Biochem. 247, 83-94

24- Rezzani, R., Rodella, L., Corsetti, G. and Bianchi, $\mathbf{R}$. (2001): Does methylene blue protect the kidney tissues from damage induced by cyclosporin A treatment? Nephron 89, 329-336

25- Callaway, N. L., Riha, P. D., Bruchey, A. K., Munshi, Z. and Gonzalez-Lima, F. (2004): Methylene blue improves brain oxidative metabolism and memory retention in rats. Pharmacol. Biochem. Behav. 77, 175-181

26- Furian, A. F., Fighera, M. R., Oliveira, M. S., Ferreira, A. P., Fiorenza, N. G., de Carvalho Myskiw, J., Petry, J. C., Coelho, R. C., Mello, C. F. and Royes, L. F. (2007): Methylene 
blue prevents methylmalonateinduced seizures and oxidative damage in rat striatum. Neurochem. Int. 50, 164-171

27- Callaway, N. L., Riha, P. D., Wrubel, K. M., McCollum, D. and Gonzalez-Lima, F. (2002): Methylene blue restores spatial memory retention impaired by an inhibitor of cytochrome oxidase in rats. Neurosci. Lett. 332, 83-86

28- Zhang, Z. J., Berbos, T. G. and Wiley, R. G. (1996): Loss of nucleus basalis magnocellularis, but not septal, cholinergic neurons correlates with passive avoidance impairment in rats treated with 192-saporin. Neuroscience Letters 203 (3), 214-218.

29- Raghuveeran, C.D. (1985): Reversed phase ion-pair chromatographic separation of acetylcholine and choline. $J$. liquid chromatography 8(3): 537544

30- Ellman, G. L., Courtney, K.D., Andres, V. Jr. and FeatherStone, R.M. (1961): A new and rapid colorimetric determination of acetylcholinesterase activity. Biochem. Pharmacol. 7, 88-95

31- Jayatilleke, E. and Shaw, S. (1993): A high-performance liquid chromatographic assay for reduced and oxidized glutathione in biological samples. Anal Biochem 214: 452-457

32- Blois, M.S. (1958): Antioxidant determination by the use of a stable free radical. Nature, 181:1199-1200

33- Terry, A.V., Buccafusco, J.J., Herman, E.J., Callahan, P.M., Beck, W.D., Warner, S.,
Vandenhuerk, L., Bouchard, K., Schwarz, G.M., Gao, J. and Chapman, J.M. (2010): Prototypical ranitidine analog, JWS-USC-75-IX, improves information processing and cognitive function in animal models. J. Pharmaco.l Exp. Ther. [Epub ahead of print]

34- Wang, Q., Sun, L.H., Jia, W., Liu, X.M., Dang, H.X., Mai, W,L., Wang, N., Steinmetz, A., Wang, Y.Q. and Xu, C.J. (2010): Comparison of ginsenosides $\mathrm{Rg} 1$ and $\mathrm{Rb} 1$ for their effects on improving scopolamine-induced learning and memory impairment in mice. Phytother. Res.; 24(12):17481754.

35- Wong, K.K., Ho, M.T., Lin, H.Q., Lau, K.F., Rudd, J.A., Chung, R.C., Fung, K.P., Shaw, P.C. and Wan, D.C. (2010): Cryptotanshinone, an acetylcholinesterase inhibitor from Salvia miltiorrhiza, ameliorates scopolamine-induced amnesia in Morris water maze task. Planta Med.; 76(3):228-34.

36- Härtl, R., Gleinich, A. and Zimmermann, M. (2010): Dramatic increase in readthrough acetylcholinesterase in a cellular model of oxidative stress. $J$. Neurochem., [Epub ahead of print]

37- Wu, H., Zhang, R., Liu, J., Guo, Y. and Ma E. (2010): Effects of malathion and chlorpyrifos on acetylcholinesterase and antioxidant defense system in Oxya chinensis (Thunberg) (Orthoptera: Acrididae). 
Chemosphere. [Epub ahead of print]

38- Bansal, N. and Parle, $M$. (2010): Soybean Supplementation Helps Reverse Age- and Scopolamine-Induced Memory Deficits in Mice. J. Med. Food. [Epub ahead of print]

39- Samadi, A., Valderas, C., de los Ríos, C., Bastida, A., Chioua, M., González-Lafuente, L., Colmena, I., Gandía, L., Romero, A., Del Barrio, L., Martín-de-Saavedra, M.D., López, M.G., Villarroya, M. and Marco-Contelles J. (2011): Cholinergic and neuroprotective drugs for the treatment of Alzheimer and neuronal vascular diseases. II. Synthesis, biological assessment, and molecular modelling of new tacrine analogues from highly substituted 2-aminopyridine-3-carbonitriles. Bioorg. Med. Chem.; 19(1):122133.

40- Bruchey, A.K. and GonzalezLima, F. (2008): Behavioral, physiological and biochemical hormetic responses to the autoxidizable dye methylene blue. Am. J. Pharm. \& Toxicol., 3: 69-76

41- Lorke, D.E., Hasan, M.Y., Nurulain, S.M., Shafiullah, M., Kuča, K. and Petroianu, G.A. (2010): Pretreatment for acute exposure diisopropylfluorophosphate: in vivo efficacy of various acetylcholinesterase inhibitors. $J$. Appl. Toxicol., [Epub ahead of print]

42- Atamna, H., Nguyen, A., Schultz, C., Boyle, K.,
Newberry, J., Kato, H. and Ames, B. N. (2008): Methylene blue delays cellular senescence and enhances key mitochondrial biochemical pathways. FASEB $J$. 22, 703-712

43- Gabrielli, D., Belisle, E., Severino, D., Kowaltowski, A. J. and Baptista, M. S. (2004): Binding, aggregation and photochemical properties of methylene blue in mitochondrial suspensions.

Photobiol., 79, 227-232

44- Riha, P.D., Bruchey, A.K., Echevarria, D.J. and GonzalezLima, F. (2005): Memory facilitation by methylene blue: dose-dependent effect on behavior and brain oxygen consumption. Eur. J. Pharmacol.; 511(2-3):151-158.

45- Zhang, X., Rojas, J.C. and Gonzalez-Lima, F. (2006): Methylene blue prevents neurodegeneration caused by rotenone in the retina. Neurotox Res., 9 (1):47-57.

46- Gonzalez-Lima, F. and Bruchey, A. K. (2004): Extinction Memory Improvement by the Metabolic Enhancer Methylene Blue. Learn. \& Mem. 11:633-640

47- Wrubel, K.M., Riha, P.D., Maldonado, M.A., McCollum, D. and Gonzalez-Lima F. (2007): The brain metabolic enhancer methylene blue improves discrimination learning in rats. Pharmacol Biochem Behav., 86 (4):712-717.

48- Peter, C., Hongwan, D., Kupfer, A. and Lauterburg, B.H. (2000): Pharmacokinetics 
and organ distribution of intravenous and oral methylene blue. Eur J Clin Pharmacol., 56(3):247-250.

49- Martijn, C. and Wiklund, L. (2010): Effect of methylene blue on the genomic response to reperfusion injury induced by cardiac arrest and cardiopulmonary resuscitation in porcine brain. BMC Medical Genomics, 3, 27: 1-19

50- Thatcher, G.R.J., Bennett, B.M., Dringenberg, H.C. and Reynolds, J.N. (2004): Novel nitrates as NO mimetics directed at Alzheimer's disease. Alzheimer's Dis 6: S75-S84

51- Kim, D. H., Hyun, S. K., Yoon, B.H., Seo, J., Lee, K., Cheong, J.H., Jung, S.Y., Jin, C., Choi,
J.S. and Ryu, J.H. (2009): Gluco-obtusifolin and its aglycon, obtusifolin, attenuate scopolamine-induced memory impairment. J. Pharmacol Sci., $111,110-116$

52- Kumar, R., Jaggi, A.S. and Singh, N. (2010): Effects of erythropoietin on memory deficits and brain oxidative stress in the mouse models of dementia. Korean J Physiol Pharmacol. 14: 345-352,

53- Nieoullon A. (2010): Acetylcholinesterase inhibitors in Alzheimer's disease: further comments on their mechanisms of action and therapeutic consequences. Psychol. Neuropsychiatr Vieil.; 8(2):123131.

$$
\begin{aligned}
& \text { التأثيرات الوقائية لمادة المثيللين الازرق ضد فقدان الذاكرة الناجم عن حقن }
\end{aligned}
$$

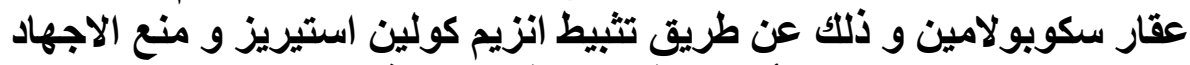

$$
\begin{aligned}
& \text { التأكسدي في الجزذان البالغة فئة } \\
& \text { أحمد محد شداتة } \\
& \text { قسم الفسيولوجي- الهيئة القومية للرقابة و البحوث الدوائية }
\end{aligned}
$$

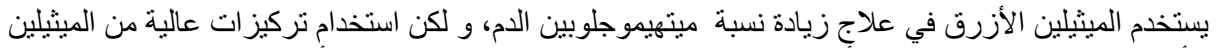

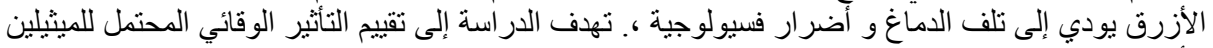

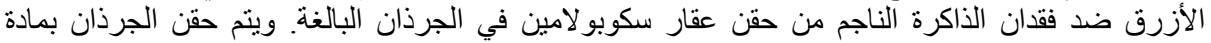

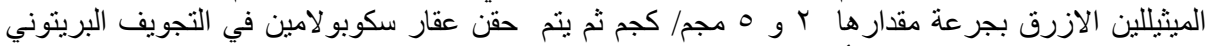

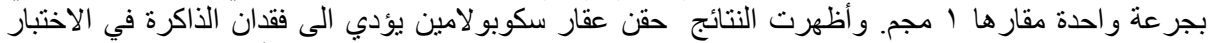

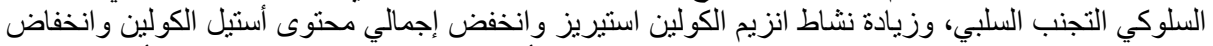

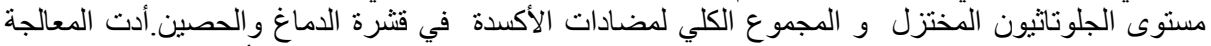

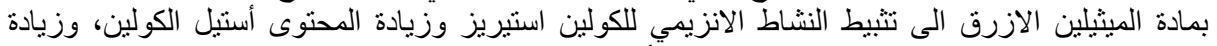

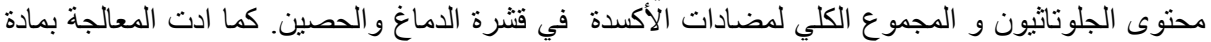

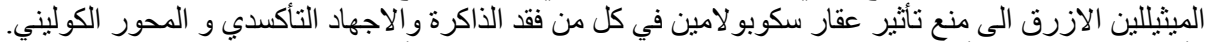

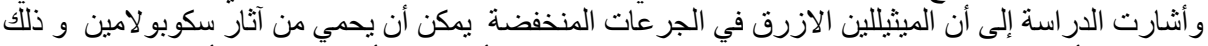

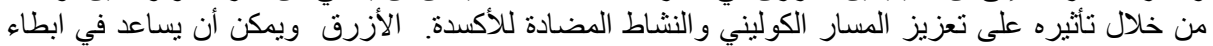

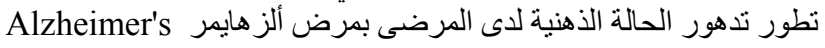

